\title{
KONVERGENSI KECOCOKAN TEKNOLOGI DENGAN KEBUTUHAN KONSUMEN DAN FUNGSIONALITAS LAYANAN MOBILE BROADBAND TERHADAP PERILAKU USE DIFFUSION
}

\author{
Widya Granita \\ Doctoral Management Student at Mercu Buana University Jakarta \\ granitawidya@gmail.com \\ Ngadino Surip \\ Faculty of Economics and Business Mercu Buana University Jakarta \\ dinosurip@gmail.com \\ Yuli Harwani \\ Program Study Doctoral, Mercu Buana University Jakarta \\ yuli_harwani@mercubuana.ac.id \\ Rina Astini \\ Program Study Doctoral, Mercu Buana University Jakarta \\ rina_astini@mercubuana.ac.id
}

\begin{abstract}
Abstrak: Konvergensi Kecocokan Teknologi dengan Kebutuhan Konsumen dan Fungsionalitas Layanan Mobile Broadband terhadap Perilaku Use Diffusion. Kesesuaian teknologi jaringan seluler dan perangkat dengan kebutuhan pengguna menentukan penggunaan dan membentuk perilaku penggunaan. Penelitian ini dilakukan untuk menganalisis interaksi antara kebutuhan teknologi fit dan perilaku penggunaan layanan broadband. Data diperoleh melalui survei di wilayah Jakarta. Sampel yang dikumpulkan dari 258 responden adalah pengguna layanan seluler prabayar dan pascabayar dari lima operator di Indonesia. Teknik pengambilan sampel menggunakan purposive sampling dan metode analisis data menggunakan Structural Equation Modeling (SEM). Hasil penelitian menghasilkan (1) NTF berpengaruh positif terhadap perilaku difusi penggunaan (intensitas dan variasi dalam penggunaan) (2) TFF berpengaruh positif terhadap perilaku penggunaan, (3) Intensitas penggunaan berpengaruh positif pada NTF dan TFF, (4) Variasi dalam penggunaan berpengaruh positif pada NTF dan TFF, (5) NTF, TFF saling mempengaruhi secara positif dengan intensitas penggunaan dan variasi penggunaan. Penelitian lebih lanjut direkomendasikan untuk meningkatkan perilaku pengguna dari perspektif pemain industri telekomunikasi lainnya seperti pengembang konten dan aplikasi serta produsen perangkat.
\end{abstract}

Kata kunci: Kesesuaian Teknologi, Kebutuhan, Perangkat, layanan mobile broadband, Perilaku penggunaan

\begin{abstract}
The convergence of Technology Fit with Consumer Needs and Broadband Service Functionality for the Use of Diffusion Behavior. The fit of technology for networks and devices with user needs determines the use and shapes usage behavior. This research was conducted to analyze the interplay of the need technology fit and the usage behavior of mobile broadband services. Data obtained through a survey in the Jakarta area. The samples collected from 258 respondents are prepaid and postpaid mobile service users from five operators in Indonesia. The sampling technique used purposive sampling and data analysis methods using Structural Equation Modeling (SEM). The results of the study found (1) NTF had a positive effect on use diffusion behavior (intensity and variety in use) (2) TFF had a positive effect on usage behavior, (3) Intensity of use had a positive effect on NTF and TFF, (4) Variation in use had a positive effect on NTF and TFF, (5) NTF, TFF is interplay positively with the intensity of use and use variety. More research is recommended to improve user behavior from the perspective of other telecommunications industry players such as content and application developers and device manufacturers.
\end{abstract}

Keywords: Technology Fit, Needs, Device, mobile broadband service, Usage behavior 


\section{PENDAHULUAN}

Mobile Broadband atau mobile internet kini menjadi layanan yang tidak bisa lepas dari keseharian kita. Perilaku gaya hidup digital yang selalu menginginkan konektivitas di setiap waktu di semua tempat melalui sebuah gawai yang selalu aktif melalui jaringan seluler handal sehingga pelanggan mendapat kualitas layanan yang prima dari Mobile Network Operator (MNO) (Gazis et al. 2003). Mobile broadband merupakan jaringan elektronik yang menghubungkan orang dan informasi melalui komputer dan media digital lainnya. Pengguna dapat menikmati konektivitas nirkabel untuk mengakses aplikasi, layanan bernilai tambah dan beragam konten multimedia melalui kombinasi sistem nirkabel ini. Secara teknis, infrastruktur internet terhubung pada media digital melalui jaringan telekomunikasi seluler yang disediakan oleh operator seluler atau MNO serta dapat diakses secara bergerak atau mobile melalui sebuah gawai seluler (Flew, 2005).

Telepon seluler adalah teman di setiap waktu yang menyimpan data pribadi, digunakan secara aktif dalam beragam aktivitas keseharian kita. Istilah handphone atau telepon selular, di Inggris disebut dengan mobile, di Amerika Serikat cell phone, di Amerika Latin cellular, di Jepang keitai (portabel), di China shou-ji (mesin tangan), di Bangladesh muthophone (telepon di telapak tangan), di Swedia nalle (teddy bear), di Israel telephone (telepon ajaib), dan di Jerman handy (edition.CNN.com), sedangkan di Indonesia muncul sebutan telepon seluler yang kemudian disingkat menjadi ponsel (Soegardo, 2017).

Pengguna seluler telah mengganti platform komunikasi konvensional atau legacy service yakni voice dan sms, beralih pada layanan data. Berdasarkan data (APJII and MASTEL, 2018), Tingkat Rata-rata Pendapatan per Pengguna atau Average Rate Per User (ARPU) pelanggan Tiga besar operator seluler nasional mengalami tekanan pendapatan rerata per pengguna pada semester pertama 2017, sebagai dampak perkembangan teknologi yang menggeser tren penggunaan layanan dari legacy menjadi layanan data. Berdasarkan laporan keuangan tiga operator seluler di Indonesia (2018) di tahun 2017 saja, ARPU PT Indosat Tbk disebutkan merosot hingga 13,3\% menjadi Rp 22500 dari perolehan periode yang sama di tahun 2016 yakni Rp 26000. Pergeseran penggunaan layanan dari suara dan pesan singkat menjadi data internet dengan tarif lebih rendah merupakan realitas yang tak bisa dihindari. Di sisi lain, operator seluler PT. XL Axiata Tbk. mengalami penurunan ARPU sebesar 8\% pada semester pertama 2017 menjadi Rp 34000 dari semula Rp 37000. PT. Telekomunikasi Selular (Telkomsel) hanya 
mengalami pertumbuhan ARPU sebesar 0,5\% dan berada di kisaran angka Rp. 44000.

Di Indonesia dengan jumlah penduduk sebesar 272.1 juta jiwa terdapat 338.2 juta (124\%) orang pengguna seluler dimana 175.4 juta diantaranya merupakan pengguna internet dan sebanyak 160 juta pengguna sosial media (Hootsuit We're Social Survey, 2020). Faktor perubahan spesifik di industri seluler adalah peningkatan lalu lintas (trafik) penggunaan layanan data seluler, dan penurunan pendapatan yang konstan dari trafik layanan suara, sehingga Average Rate per Usage (ARPU) menurun (Ministry of Communication and Informatics 2018). Peningkatan lalu lintas data terjadi sebagai akibat langsung dari penyebaran layanan bernilai tambah oleh penyedia aplikasi overthe-top (D. H. Shin dan Jin Park 2017), semakin populernya layanan bandwidth seperti streaming video dan peer to peer, dan munculnya paket data plan yang lebih mudah diakses dengan harga terjangkau, juga popularitas layanan jejaring sosial (beberapa di antaranya termasuk aplikasi multimedia seperti berbagi foto dan video), serta difusi ponsel pintar yang mudah digunakan untuk mengakses internet. Oleh karena itu, inovasi teknologi merupakan komponen utama dalam industri telekomunikasi seluler (Du Preez dan Pistorius 2003; Fernández dan Usero 2009).
Di sisi lain, munculnya gawai seluler yang disesuaikan untuk penggunaan Internet (yaitu, ponsel pintar dan tablet) dan difusi konten yang mengkonsumsi banyak layanan data seperti streaming video mendorong penggunaan layanan data dalam mobilitas (De Reuver, Ongena dan Bouwman 2013). Inovasi dan investasi dalam infrastruktur teknologi jaringan seluler meningkatkan ketersediaan dan kualitas layanan data dengan kecepatan akses yang lebih tinggi (Ghezzi, Cortimiglia dan Frank 2015). Namun demikian, tarif data seluler cenderung menjadi lebih rendah sejalan dengan bertumbuhnya beragam bisnis digital. Dalam lingkungan persaingan di industri telekomunikasi seluler yang kompleks ini, elemen regulasi turut berperan dalam mengubah kebutuhan dan perilaku pelanggan karena memposisikan persaingan antar operator menjadi lebih kompetitif, sehingga menjadi faktor penting bagi operator seluler dalam menyusun strategi bisnisnya (Zhang dan Liang 2011).

Peningkatan pendapatan operator seluler terjadi melalui penggunaan layanan berdasarkan intensitas penggunaan yang tinggi dan banyaknya variasi penggunaan layanan yang ditawarkan secara bersamaan. Pola perilaku pengunaan merupakan hasil dari proses use diffusion yang menunjukkan bahwa layanan teknologi yang sesuai dengan kebutuhan pengguna diiringi karakteristik 
gawai akan diadopsi konsumen. Penelitian ini bertujuan untuk membentuk perilaku penggunaan (intensitas dan variasi penggunaan) yang dibangun atas kecocokan teknologi dengan kebutuhan pengguna serta interoperabilitas teknologi dengan bergam gawai sehingga dapat mengakses layanan seluler.

Pada penelitian ini, grand theory perilaku penggunaan dari use diffusion model (Ram dan Jung 1990) menjadi dasar pengkajian penelitian. Konseptualisasi penggunaan terdiri dari dua dimensi yang berbeda: variasi atau ragam penggunaan (use variety) dan tingkat intensitas penggunaan (use intensity). Ragam penggunaan mengacu pada berbagai cara dan banyaknya produk atau layanan digunakan. Intensitas penggunaan mengacu pada banyaknya waktu untuk menggunakan produk atau layanan selama periode yang ditentukan. Meskipun dapat dibayangkan bahwa variasi dan penggunaan saling berkorelasi yaitu semakin tinggi ragamnya, semakin tinggi tingkat penggunaannya, namun hubungan sebenarnya tidak diuji secara empiris.

Teori utama Use Diffusion (Ram and Jung 1990) dan temuan klasik Ridgeway \& Price, (1994) mencatat bahwa tingkat penggunaan yang lebih tinggi tanpa ragam penggunaan yang lebih tinggi mengindikasikan adanya kebutuhan rutin. Selanjutnya, faktor anteseden yang berbeda dapat mempengaruhi frekuensi atau intensitas dan ragam penggunaan, dan karenanya harus diperlakukan berbeda pula. Kombinasi ragam penggunaan (banyak atau sedikit) dan intensitas penggunaan (rendah atau tinggi) menghasilkan pola penggunaan yakni: penggunaan intens, khusus, tidak terspesialisasi, dan penggunaan terbatas. Penggunaan yang intens menggambarkan inovasi digunakan untuk tataran yang signifikan dari sisi intensitas penggunaan (waktu konsumsi per minggu) dan variasi ragam penggunaan (jumlah layanan atau aplikasi). Pada penggunaan khusus (specialized), terlihat pada intensitas penggunaan yang bertambah. Perilaku penggunaan semacam itu pada dasarnya memperlakukan inovasi sebagai perangkat khusus (Sawng, Motohashi, dan Kim 2013). Pengguna nonspesifik mengacu pada pola penggunaan di mana ragam penggunaan lebih penting daripada tingkat penggunaan. Pola seperti ini merupakan yang terbaik meskipun mencerminkan penggunaan berdasarkan trial and error. Terakhir, penggunaan terbatas mengacu pada variasi dan intensitas penggunaan yang rendah. Artinya, pengguna tidak menemukan aplikasi potensial dan jika pun ada sangat kecil, maka pengguna akan mengalihkan peran produk menjadi relatif kecil, bahkan sampai pada titik "disadoption" (Venkatesh, Kruse, dan Shih 2003). 
Namun demikian Shih dan Venkatesh (2004) menegaskan bahwa tipe pengguna tidak perlu diubah dari waktu ke waktu, karena pengguna dapat berpindah dari satu kategori ke kategori lainnya mengingat kebutuhan dan faktor situasional lainnya. Misalnya, pengguna yang intens dapat menyesuaikan diri dengan rutinitas penggunaan terbatas di setiap waktu, sehingga dapat direklasifikasikan sebagai pengguna khusus. Dinamika semacam ini terjadi di antara tipe pengguna yang tidak jarang terjadi dalam konteks pemasaran. Hal ini sejalan dengan penelitian psikografis di mana orang mengalami perubahan gaya hidup dan beralih dari satu kategori ke kategori lainnya.

Model penelitian perilaku use diffusion ini dibangun berdasarkan Needs Technology Fit (NTF). Lin (2016) menggunakan model task technology fit sebagai dasar keputusan penggunaan suatu layanan, menemukan bahwa konvergensi motivasi kebutuhan konsumen dan karakteristik teknologi dapat memenuhi kebutuhan penggunanya. Selain itu perilaku use Diffusion juga dibangun dari Device Technology Fit (Negahban and Chung 2014). Hal ini didukung temuan awal Srinuan, Srinuan, and Bohlin (2013), layanan data atau Mobile broadband umumnya didefinisikan sebagai penggunaan internet melalui gawai seluler canggih, disebut ponsel pintar atau smartphone. Model UD memiliki kemampuan teoritis dan praktis yang superior dibandingkan model adopsi-difusi dalam menjelaskan kebutuhan dan pola perilaku konsumen yang menginginkan layanan yang lebih canggih dan terkonvergensi di pasar berteknologi tinggi (Motohashi et al. 2012). Berdasarkan kajian penelitian terdahulu, penelitian ini perlu dilakukan untuk menganalisis needs technology fit dan technology functionality fit untuk membentuk perilaku penggunaan yang sifatnya berulang, sehingga meningkatkan penggunaan berkelanjutan.

Dengan demikian akan diperoleh pola penggunaan untuk dapat meningkatkan ARPU sehingga menambah pendapatan MNO.

\section{KAJIAN LITERATUR}

\section{Task Technology Fit (TTF)}

Teori TTF Goodhue dan Thompson (1995), merupakan teori utama dengan model kesesuaian teknologi dengan kebutuhan tugas pengguna, di mana teknologi yang ada dimanfaatkan untuk mendukung penyelesaian tugas-tugas pengguna. Secara lebih mendalam, TTF mengeksplorasi kecocokan antara teknologi, tugas, dan pengguna. Jika teknologi mendukung kebutuhan untuk penyelesaian tugas lebih baik tentu akan meningkatkan kinerja, maka pengguna akan menjadikan hal 
ini sebagai landasan dalam penggunaan teknologi melalui layanan operator seluler yang dipilihnya.

Goodhue dan Thompson 1995 mengembangkan ukuran kecocokan tugasteknologi yang terdiri dari delapan faktor: kualitas, melokalisir, otorisasi, kompatibilitas, kemudahan penggunaan, ketepatan waktu produksi, keandalan sistem, dan hubungan dengan pengguna. Melalui pengukuran TTF ditemukan hubungan layanan teknologi dengan penggunaan yang menjadi prediktor signifikan peningkatan kinerja dan efektivitas pekerjaan dengan penggunaan sistem yang sedang diteliti. Sejak awal, TTF telah diterapkan dalam konteks beragam sistem informasi termasuk sistem perdagangan elektronik. TTF digunakan sebagai perpanjangan dari model lain yang terkait dengan hasil teknologi informasi seperti Model Penerimaan Teknologi (TAM).

Pengukuran pada TTF yang disajikan telah mengalami banyak modifikasi yang sesuai dengan tujuan studi tertentu. (Lu and Yang 2014; Yen et al. 2010; Klopping dan Mckinney 2004; K. Y. Lin 2016) menyatakan bahwa teknologi informasi mendorong penggunaan secara aktif hanya jika memiliki fitur memenuhi kebutuhan tugas pengguna secara fungsional. Model TTF terdapat pada Gambar 1.

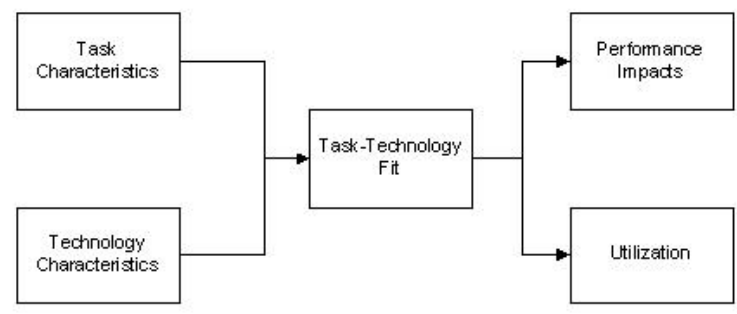

Gambar 1. Model Task Technology Fit Sumber: Goodhue dan Thompson (1995)

Dari perspektif kognisi pengguna, kesesuaian antara karakteristik tugas dan teknologi merupakan faktor utama yang secara langsung mempengaruhi niat untuk menggunakan teknologi informasi yang akan meningkatkan kinerja. Hal ini menunjukkan bahwa tingkat kesesuaian antara tugas, teknologi, dan pengguna mempengaruhi kinerja yang pada gilirannya mempengaruhi perilaku menggunakan teknologi.

Di masa lalu, TTF banyak digunakan untuk mengeksplorasi kinerja sistem informasi di dalam perusahaan dengan mengamati karakteristik tugas karyawan serta sistem yang ada. Oleh karena itu, kerangka kerja TTF belum diterapkan pada bidang lain atau mengeksplorasinya secara individu. Namun demikian, dengan mempertimbangkan bahwa pengguna sebagai individu, beberapa peneliti (Klopping dan Mckinney 2004; W. Lin 2012; Yen et al. 2010b) mengadopsi TTF sebagai dasar teori untuk mengeksplorasi perilaku penggunaan pada bidang lain. Dengan menggunakan TTF, (Yen et al. 2010a) melakukan penelitian tentang faktor-faktor 
yang mempengaruhi penerimaan terhadap teknologi nirkabel, misalnya operator seluler. Hasilnya menunjukkan bahwa tingkat kesesuaian antara tugas dan teknologi berpengaruh terhadap penggunaan jaringan operator seluler.

Lu dan Yang (2014) mengusulkan sebuah model social-technology fit sesuai teknologi berbasis TTF untuk memprediksi perilaku pemakaian pengguna situs jejaring sosial. Temuan penelitian menunjukkan bahwa kebutuhan yang berorientasi sosial memberi pengaruh lebih besar pada niat penggunaan sosial media Facebook, dibandingkan dengan kebutuhan pemenuhan tugas. Untuk mempelajari sejauh mana kesesuaian antara teknologi blog dan kebutuhan sosial pengguna jejaring sosial mempengaruhi perilaku penggunaan, Kwai Fun IP dan Wagner (2008) mengadopsi model kebutuhan sosial blogger dan mengajukan kebutuhan teknologi sebagai kerangka penelitian. Hasilnya menunjukkan bahwa adanya kesesuaian antara kebutuhan blogger dan karakteristik teknologi dalam meningkatkan perilaku penggunaan blogger. Berdasarkan studi empiris diatas telah mengungkapkan bahwa TTF dianggap sebagai teori esensial dalam hal mengeksplorasi faktor-faktor yang mempengaruhi perilaku orang menggunakan media sosial (Kwai Fun IP and Wagner 2008; Lu dan Yang 2014).
Dalam pengambilan keputusan TTF dikembangkan untuk memahami pengguna dalam memilih dan mengevaluasi layanan seluler, dimana kebutuhan individu terpenuhi dengan kesesuaian teknologi (Dishaw dan Strong 1998). Merujuk pada teori Task Technology Fit (Goodhue and Thompson 1995), digunakan untuk membantu dalam pengambilan keputusan memilih layanan IT. (Liu, Guo, dan Lee 2011) menginterprestasikan bahwa konsep 'fit' adalah indikasi kesesuaian dan kesatuan perspektif antara motivasi kebutuhan individu dan keputusan pembelian. Pendekatan operasionalisasi fit yaitu kesesuaian antara task dan technology; dan kesesuaian fungsi layanan teknologi yang digunakan.

$$
\text { Kottler dan Armstrong }
$$
menyatakan bahwa keputusan pembelian adalah tahap evaluasi, dimana konsumen membangun preferensi antar merek dalam kumpulan pilihan. Dalam melaksanakan niat pembelian konsumen membuat sub keputusan: pilihan merek, produk, penyalur, kuantitas pembelian, waktu pembelian, dan metode pembayaran. Hal ini selaras dengan penyataan (Goodhue dan Thompson 1995) bahwa komponen TTF terdiri dari dimensi: kualitas data, locatability, otorisasi akses data; data compatibility, training dan kemudahan penggunaan, linimasa, sistem kompatibilitas, dan hubungan teknologi 
dengan pengguna. Penelitian ini menggunakan model TTF sebagai dasar keputusan dalam memilih operator seluler.

\section{Use Diffusion Model}

Model penggunaan difusi (UDM), merupakan pendekatan alternatif dari adopsi inovasi ke penggunaan inovasi (Shih dan Venkatesh 2004) menyatakan bahwa UDM dapat menjelaskan dan memprediksi proses difusi teknologi inovatif dengan menjajagi pola penggunaan konsumen pada tahap paska adopsi dan untuk menentukan difusi inovasi selanjutnya. UDM dapat memperhitungkan beragam karakteristik difusi seperti dimensi penggunaan teknologi, tingkat penggunaan, dan variasi penggunaan yang berbeda untuk menentukan bagaimana inovasi akan berjalan di pasar dalam jangka waktu panjang. Dengan demikian, UDM dapat diterapkan secara luas sebagai model penjelasan difusi lebih lanjut dari produk/atau layanan yang kompleks secara teknis, seperti konvergensi beragam produk digital yang menawarkan berbagai fungsi (Kim, Chan, dan Gupta 2007).

Model UD menghubungkan pengambilan keputusan konsumen dan perilaku konsumsi. Tipologi penggunan yang diusulkan adalah penggunaan intensif (intense use), penggunaan khusus (specialized use), pengguna nonspesifik (non specialized use), dan pengguna terbatas (limited use). Model UD terbagi dalam konstruksi umum yaitu inovasi, komunikasi sosial, kompleksitas, pengaruh media, dan kemanfaatan relatif. Teori dari Hamblin, Miller, and Saxton (1979) digunakan untuk menunjukkan pada fase penggunaan dapat mencerminkan permintaan pasar, orisinalitas perilaku, dan dapat memprediksi atau menjelaskan kurva permintaan jangka panjang. (Gardial et al. 2004) membuktikan bahwa nilai yang dirasakan konsumen akan berbeda saat membeli, menggunakan dan paska penggunaan suatu produk atau layanan. Pada saat membeli (prapenggunaan, konsumen lebih mementingkan atribut produk. Pada fase menggunakan dan pasca- penggunaan, konsumen fokus pada hasil yang diperoleh. Konsumen memiliki keinginan saat melakukan pembelian, membayangkan produk atau layanan sesuai yang keinginannya. Sedangkan pada pascapenggunaan konsumen akan benar-benar merasakan nilai produk atau layanan tersebut. Lebih jelasnya, model UD dapat dilihat pada Gambar 1.

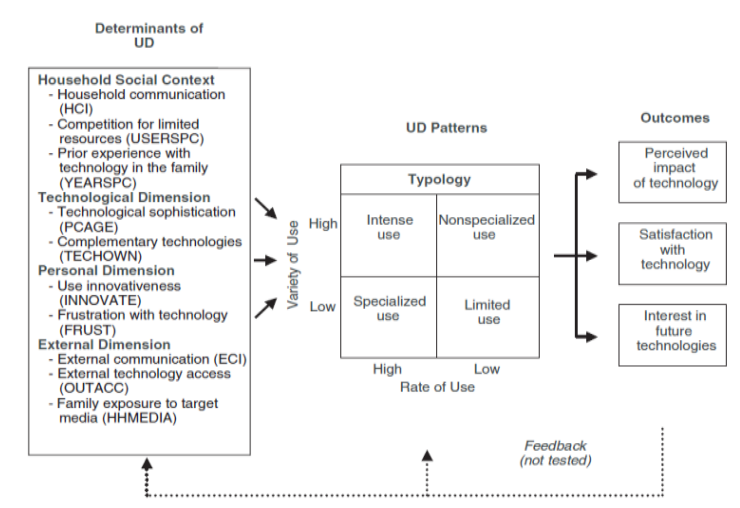


Gambar 2. Use-Diffusion Model

Sumber: Venkatesh dan Shih, 2004.

\section{Model Penelitian: Unifikasi TTF dan UDM}

Penelitian ini menggunakan empat variabel yakni: needs technology fit, technology functionality fit, use intensity dan use variety. Elemen teoritis dari TTF menjadi landasan keputusan untuk menggunakan layanan seluler dari $\mathrm{MNO}$ yang akan membentuk perilaku penggunaan. Keduanya saling berpengaruh satu sama lain sehingga dapat membentuk penggunaan berulang dan sekaligus length of stay pelanggan (LoS) sehingga loyalitas pelanggan secara simultan akan menambah pendapatan operator seluler dengan ARPU yang meningkat. Model penelitian ini terdapat pada gambar 3.

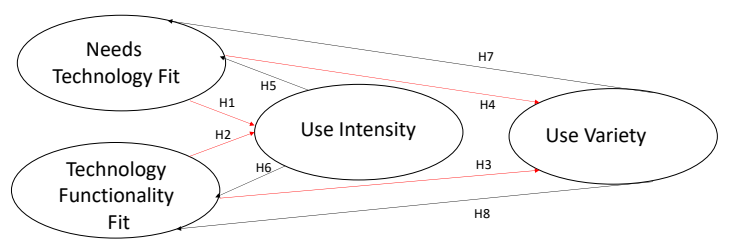

Gambar 3. Konseptual Model Penelitian

\section{Needs Technology Fit (NTF)}

Untuk mengadopsi layanan seluler konsumen harus menjadi subscribers sebuah operator seluler. Keputusan memilih ini dilandasi oleh kecocokan antara motivasi kebutuhan yang didasari oleh persepsi dan keyakinan konsumen akan keandalan teknologi seluler serta keunggulan layanan seluler yang disediakan operator.

Selanjutnya subscribers akan menggunakan layanan seluler yang mencerminkan bentuk perilaku penggunaan yang akan menuntun ke arah kepuasan dan munculnya minat terhadap penggunaan teknologi baru ketika operator melakukan pemutakhiran jaringan.

Mengingat teknologi seluler yang berubah dengan cepat dan dinamis telah membentuk perubahan perilaku konsumen, operator seluler dituntut untuk terus menawarkan layanan inovatif yang hanya bisa dilakukan dengan menggunakan teknologi seluler terkini. Untuk itu operator seluler terus menerus berinvestasi untuk infrastruktur dan jaringan, namun pada saat yang bersamaan pula perlu menemukenali dinamika pergeseran perilaku pelanggan, sehingga dapat memberikan layanan yang sesuai dengan kebutuhan dan keinginan pelanggan

Kecocokan teknologi yang didasari oleh kebutuhan akan layanan seluler, telah membentuk persepsi konsumen dalam pengambilan keputusan memilih operator seluler. Penggunaan layanan seluler yang sesuai dengan kebutuhan, tujuan atau sasaran setiap individu, namun berbeda cara dalam mencapai hasilnya, disertai pengaruh lingkungan atau konteks individu, dapat membentuk perbedaan perilaku penggunaan 
(Ramirez-Correa, Rondan-Cataluña, and Arenas-Gaitán 2015). Ketika perbedaan perilaku ini timbul, operator seluler akan memberikan keleluasaan kepada pengguna untuk mencoba berbagai alternatif layanan yang memunculkan preferensi dan menilai manfaat yang dipersepsikan pengguna $(\mathrm{Ju}$ 2011). Perilaku setiap individu tidak sama satu sama lain, demikian pula jalur pengalaman dan nilai yang dirasakan juga akan berbeda.

Penelitian (Lin 2016), mengacu pada model task technology fit dari Goodhue dan Thomson (1995) yang mempertimbangkan bahwa teknologi hanya akan digunakan jika dapat berfungsi untuk memenuhi kebutuhan pengguna dalam menyelesaikan tugas. Terdapat tiga elemen motivasi kebutuhan yang digunakan yakni kebutuhan utilarian, hedonik dan sosial. Sedangkan elemen karakteristik teknologi juga sebagai faktor utama yang mempengaruhi adopsi teknologi yaitu mobile convienience, service compatibility dan user control. Oleh sebab itu, peneliti mengemukakan hipotesa:

H1. NTF berpengaruh positif terhadap Use Intensity

H2. NTF berpengaruh positif terhadap Use Variety

\section{Technology Functionlity Fit (TFF)}

Teknologi seluler telah mengubah secara dramatis tidak hanya cara bekerja, tetapi juga cara kita hidup dan berkomunikasi satu sama lain. Hal ini berarti juga mengubah perilaku sosial dan individu, dan hubungan orang lain (Negahban and Chung 2014). Secara keseluruhan teknologi seluler telah membawa kebutuhan baru dalam hidup yang tidak pernah kita miliki sebelumnya. Jaringan seluler yang sifatnya ada di mana-mana dan memiliki multifungsi, diakses melalui sebuah ponsel pintar. Ponsel pintar dengan fitur yang sifatnya personal memungkinkan pengguna untuk menambahkan aplikasi yang berbeda berdasarkan preferensi pengguna serta menggunakannya untuk memenuhi kebutuhan hedonis atau utilitarian.

TFF diadaptasidari mobile device functionality fit (Negahban and Chung 2014) yang didasari oleh kesesuaian user requirement, network functionalities yang diakses melalui sebuah interface atau gawai. Karakteristik pengguna juga mempengaruhi TFF, sehingga adopsi layanaan teknologi adalah produk dari karakteristik tugas dan teknologi yang mempengaruhi kinerja pengguna dan penggunaan aktual (Zhou, Lu, and Wang 2010).

Konsep fit dalam konteks teknologi seluler, Gebauer, et al. (2005) mengidentifikasi 5 faktor yang sesuai untuk layaann seluler yaitu: komunikasi suara, mobile office, dukungan untuk pengetahuan, produktivitas dan keserbagunaan, fitur nirkabel dan stabilitas jaringan). Technology functionality fit sejalan dengan pemikiran 
keputusan pembelian Kottler dan Armstrong (2011) yakni pilihan produk dan waktu serta kuantitas penggunaan, dan selaras dengan komponen TTF Goodhue: system realibility (layanan yang reliabel) dan relationship with user (hubungan operator seluler dengan pengguna). Sifat unik layanan seluler yang dapat diakses darimanapun dan kapanpun melalui sebuah gawai.

Kemajuan teknologi gawai yang pesat menciptakan multifungi pada sebuah ponsel (Negahban 2012), dimana operator seluler harus terus menyediakan teknologi jaringan akses yang bersifat interoperability dengan semua jenis gawai. Gawai merupakan interface untuk terkoneksi dengan jaringan seluler, sehingga karakteristik gawai dan newtwork capabilities menjadi faktor penting dalam menggunakan layanan seluler (Sarker dan Wells 2003). Disisi lain operator seluler juga telah menyiapkan layanan pelanggan yang dapat diakses dari berbagai platform digital, sehingga keterhubungan dengan pengguna tidak pernah terputus.

Menurut (Negahban dan Chung 2014), esensi multifungsi gawai seluler melalui akses layanan broadband yang sifatnya dapat dibawa mana-mana dan dilengkapi dengan dengan beragam fitur personal memungkinkan pengguna ponsel untuk menambahkan aplikasi yang berbeda. Pengguna dapat menyesuaikan fungsi gawai seluler berdasarkan preferensi serta menggunakannya untuk memenuhi kebutuhan mereka yang bersifat kesenangan (hedonik) atau kegunaan (utilitarian). Pemikiran ini merumuskan hipotesis:

H3. TFF berpengaruh positif terhadap Use Intensity

H4. TFF berpengaruh positif terhadap Use Variety

\section{Pola Perilaku Use Diffusion}

Konseptualisasi penggunaan terdiri dari dua dimensi yang berbeda: variasi atau ragam penggunaan (use variety) dan tingkat intensitas penggunaan (use intensity). Ragam penggunaan mengacu pada berbagai cara dan banyaknya produk atau layanan digunakan. Intensitas penggunaan mengacu pada banyaknya waktu untuk menggunakan produk atau layanan selama periode yang ditentukan. Meskipun dapat dibayangkan bahwa variasi dan penggunaan saling berkorelasi yaitu semakin tinggi ragamnya, semakin tinggi tingkat penggunaannya, namun hubungan sebenarnya tidak diuji secara empiris.

Teori use diffusion Ram dan Jung mencatat bahwa tingkat penggunaan yang lebih tinggi tanpa ragam penggunaan yang lebih tinggi mengindikasikan adanya kebutuhan rutin. Selanjutnya, faktor anteseden yang berbeda dapat mempengaruhi frekuensi dan variasi penggunaan, dan karenanya harus diperlakukan berbeda pula. Kombinasi ragam penggunaan (banyak atau 


\section{Nominal: Barometer Riset Akuntansi dan Manajemen}

P-ISSN: 2303-2065 E-ISSN: 2502-5430

Volume 9 No 1 (2020)

sedikit) dan intensitas penggunaan (rendah atau tinggi) menghasilkan tipologi penggunaan seperti yang telah disebutkan diatas, yakni: penggunaan intens, khusus, tidak terspesialisasi, dan pengunaan terbatas. Penggunaan yang intens menggambarkan inovasi digunakan untuk tataran yang signifikan dari sisi intensitas penggunaan (waktu konsumsi per minggu) dan variasi ragam penggunaan (jumlah layanan atau aplikasi). Pada penggunaan khusus (specialized), terlihat pada intensitas penggunaan yang bertambah. Perilaku penggunaan semacam itu pada dasarnya memperlakukan inovasi sebagai layanan khusus (Sawng, Motohashi, dan Kim 2013). Pengguna nonspesifik mengacu pada pola penggunaan di mana ragam penggunaan lebih penting daripada tingkat penggunaan. Pola seperti ini merupakan yang terbaik meskipun mencerminkan penggunaan berdasarkan trial and error. Terakhir, penggunaan terbatas mengacu pada variasi dan intensitas penggunaan yang rendah. Artinya, pengguna tidak menemukan aplikasi potensial dan jika pun ada sangat kecil, maka pengguna akan mengalihkan peran produk menjadi relatif kecil, bahkan sampai pada titik "disadoption" (Ju 2011)

Namun demikian (Shih dan Venkatesh 2004) menegaskan bahwa tipe pengguna tidak perlu diubah dari waktu ke waktu, karena pengguna dapat berpindah dari satu kategori ke kategori lainnya mengingat kebutuhan dan faktor situasional lainnya. Misalnya, pengguna yang intens dapat menyesuaikan diri dengan rutinitas penggunaan terbatas di setiap waktu, sehingga dapat direklasifikasikan sebagai pengguna khusus. Dinamika semacam ini terjadi di antara tipe pengguna yang tidak jarang terjadi dalam konteks pemasaran. Hal ini sejalan dengan penelitian psikografis di mana orang mengalami perubahan gaya hidup dan beralih dari satu kategori ke kategori lainnya. Adapun hipotesa yang dirumuskan adalah:

H5. Use Intensity berpengaruh positif terhadap NTF

H6. Use Variety berpengaruh positif terhadap NTF

H7. Use Intensity berpengaruh positif terhadap TFF

H8. Use Variety berpengaruh positif terhadap TFF

\section{METODE PENELITIAN}

Penelitian ini dilakukan mengacu pada penelitian terdahulu yang dilakukan oleh (K. Y. Lin 2016) dan (Negahban and Chung 2014). Metode survey digunakan penilitian ini pada 258 responden pengguna kartu seluler di Jakarta yang diperoleh dengan pengambilan sampel dengan teknik purposive sampling. Hasil pengumpulan data dianalisis dengan Structural Equation Modelling (SEM). Selain itu, semua 
pernyataan item diukur dengan skala Likert, mulai dari 1 hingga 5, 1 = sangat tidak setuju dan 5 = sangat setuju. Survey pada penelitian menggunakan instrumen berupa kuesioner. Item yang dipilih sedikit dimodifikasi agar sesuai dengan konteks layanan seluler. Item yang mengukur needs technology fit diadaptasi dari studi Lin (2016) dan Sarker dan Wells (2003), technology functionality fit didasari dari studi (J. Shin, Choi, dan Lee 2016). Untuk mengukur perilaku penngunaan di adaptasi dari studi Shih dan Venkatesh (2004) serta teori use diffusion Ram dan Jung, dimana intensitas penggunaan dan ragam penggunaan merupakan variabel dari perilaku penggunaan.

Sebelum didistribusikan, dilakukan Uji Validitas dan Reliabilitas terhadap instrumen penelitian untuk mendapatkan alat ukur yang valid dan andal. Uji validitas dilakukan dengan menggunakan Analisis Faktor Konfirmatori, mengacu pada pemuatan faktor dari masing-masing indikator dan AVE (Average Variance Extracted) dari masing-masing konstruk sebagai ukuran validitas konvergen.

\section{HASIL PENELITIAN DAN PEMBAHASAN}

Dari tabel 1 dapat dilihat bahwa validitas dan reliabilitas variabel laten seluruh konstruk berada pada kisaran 0.64 sampai 0.95 adalah baik, karena memenuhi syarat validitas indikator dengan nilai SLF $\geq$
0,50. Nilai Construct Reliability sebesar kisaran 0.8371 sampai 0.9186 sudah memenuhi nilai $\mathrm{CR}$ yang baik yakni $\geq 0,70$. Nilai Variance Extracted antara 0.5654 sampai 0.8496 sudah memenuhi syarat nilai VE yang baik yaitu $\geq 0,50$. Hasil analisis ini menunjukkan bahwa bahwa seluruh indikator NTF, TTF, IP dan RP mampu menjelaskan dengan baik maksud dari teknologi seluler dan fungsi gawai cocok untuk memenuhi kebutuhan sehingga membentuk intensitas dan ragam penggunaan layanan seluler. Hasil selengkapnya terdapat pada Tabel 1 .

Penelitian dilakukan terhadap 258 responden dari populasi pengguna seluler baik kartu prabayar dan paska bayar di wilayah DKI Jakarta. Pengumpulan data dilakukan pada pengguna seluler prabayar dan paska bayar dari lima (5) operator seluler di Indonesia yakni: Telkomsel, Indosat Ooredo, XL Axiata, 3 Hutchinson dan Smarfren yang berada berada di kota Jakarta.

Penelitian dilakukan secara langsung di lapangan melalui survei konsumen dengan metode wawancara tatap muka menggunakan kuesioner yang diisi oleh responden penelitian. Selain itu dilakukan survei secara daring yang diikuti dengan wawancara tatap muka secara digital menggunakan video call. Kriteria responden adalah kaum muda berusia 18-30 tahun, menggunakan kartu seluler prabayar atau paskabayar dengan 
lama penggunaan lebih dari tiga bulan. Dari semua data yang dikumpulkan berdasarkan karakteristik responden, mayoritas responden adalah perempuan (54.26\%), usia di 16-25 tahun tahun dengan latar belakang mahasiswa $(78,68)$, pendapatan > 1-2 juta rupiah / per bulan. Sedangkan responden minoritas adalah laki-laki (45,74\%), usia 1625 tahun, latar belakang mahasiswa $(21,32 \%)$, pendapatan $<1-2$ juta rupiah / per bulan (3\%).

Tabel 1. Validitas dan reliabilitas Variabel

Laten

\begin{tabular}{|c|c|c|c|c|c|}
\hline \multirow{2}{*}{$\begin{array}{c}\text { Konstru } \\
\mathbf{k}\end{array}$} & \multicolumn{3}{|c|}{ Loadi } & \multirow[b]{2}{*}{$\mathbf{C R}$} & \multirow[b]{2}{*}{ VE } \\
\hline & Indikato & ng & Error & & \\
\hline \multirow{7}{*}{ NTF } & Kegunaa & 0.84 & 0.30 & \multirow{6}{*}{0.8569} & \\
\hline & n & & & & \\
\hline & menyele & & & & \\
\hline & $\begin{array}{l}\text { saikan } \\
\text { tugas }\end{array}$ & & & & 0.7497 \\
\hline & $\begin{array}{l}\text { Memenu } \\
\text { hi }\end{array}$ & 0.89 & 0.20 & & \\
\hline & $\begin{array}{l}\text { kesenan } \\
\text { gan }\end{array}$ & & & & \\
\hline & Fungsi & 0.82 & 0.33 & \multirow{12}{*}{0.8371} & \\
\hline \multirow[t]{11}{*}{ TFF } & $\begin{array}{l}\text { interkon } \\
\text { ektivitas } \\
\text { gawai }\end{array}$ & & & & \\
\hline & Fungsi & 0.84 & 0.30 & & \\
\hline & akses . & & & & \\
\hline & aplikasi & & & & 0.5654 \\
\hline & & 0.69 & 0.52 & & \\
\hline & gawai & & & & \\
\hline & Gawai & 0.64 & 0.59 & & \\
\hline & berfungs & & & & \\
\hline & i sesuai & & & & \\
\hline & keingina & & & & \\
\hline & $\mathrm{n}$ & & & & \\
\hline \multirow[t]{4}{*}{ IP } & Penggun & 0.84 & 0.30 & \multirow{4}{*}{0.8569} & \\
\hline & a-an & & & & \\
\hline & $\begin{array}{l}\text { setiap } \\
\text { waktu }\end{array}$ & & & & 0.7497 \\
\hline & $\begin{array}{l}\text { Penggun } \\
\text { aan }>5\end{array}$ & 0.89 & 0.20 & & \\
\hline
\end{tabular}

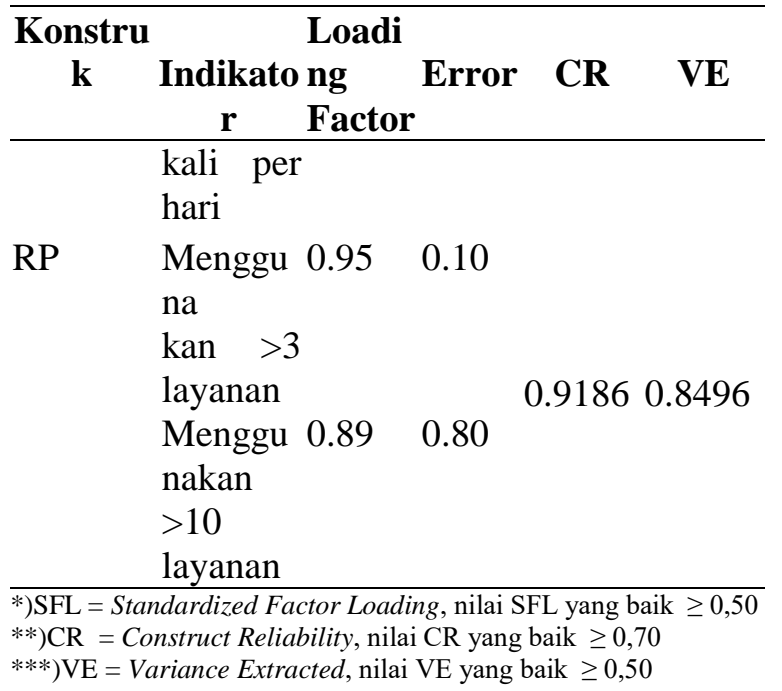

Metode analisis data yang digunakan dalam penelitian ini adalah Structural Equation Model (SEM). Sebelum membuat hipotesis, semua model (model fit keseluruhan), terlebih dahulu dinilai untuk memastikan bahwa model tersebut mampu menggambarkan semua ikatan dan efek (goodness of fit). Jika seluruh model yang dibangun dalam penelitian ini dinyatakan baik, maka uji hipotesis akan dilanjutkan. Hasil pengujian model dengan berbagai pengukuran goodness-offit dapat dilihat pada Tabel 2 menunjukkan ukuran kecocokan incremental fit model yaitu membandingkan model yang diusulkan dengan model dasar yang sering disebut sebagai null model atau independence model, dengan hasil nilai CFI $=0.99 ; \mathrm{NFI}=0.96 ; \mathrm{NNFI}=0.99 ; \mathrm{IFI}=0.99$ dan RFI $=0.95$. Ukuran parsimonus fit model, PGFI ukurannya yang hampir sama dengan GFI dan AGFI tetapi telah menyesuaikan terhadap pengaruh derajat bebas dan kompleksitas data AGFI $=0.96$ 
dan PGFI $=0.70$. Maka model dikatakan baik karena berada pada tingkat kriteria uji baik. Semua kriteria pengukuran goodness of fit index dengan diterima point seperti yang diharapkan Model rata-rata yang dibangun mampu menerima dalam tingkat fit. Hair et al. (2010), menyatakan bahwa jika satu atau dua kriteria good-of-fit yang memenuhi kriteria, maka dapat disimpulkan sebagai model yang baik. Sehingga dapat disimpulkan bahwa model yang dibangun dengan statistik dapat didukung dan disesuaikan dengan model yang telah ditetapkan, oleh karena itu uji Hipotesis dapat dilanjutkan.

Tabel 2 Hasil Uji Kecocokan Keseluruhan Model

\begin{tabular}{|c|c|c|c|}
\hline $\begin{array}{l}\text { Ukuran Kecocokan } \\
\text { Keseluruhan Model }\end{array}$ & $\begin{array}{c}\text { Hasil } \\
\text { Per- } \\
\text { hitunga } \\
\text { n }\end{array}$ & $\begin{array}{c}\text { Syar } \\
\text { at }\end{array}$ & $\begin{array}{c}\text { Ketera } \\
\text { ngan }\end{array}$ \\
\hline \multicolumn{4}{|l|}{$\begin{array}{l}\text { Absolute fit Model } \\
\text { Root Mean Square }\end{array}$} \\
\hline $\begin{array}{l}\text { Error of } \\
\text { Approximation } \\
\text { (RMSEA) }\end{array}$ & 0.0136 & $\begin{array}{c}\leq \\
0.08\end{array}$ & $\begin{array}{l}\text { Good } \\
\text { Fit }\end{array}$ \\
\hline $\begin{array}{l}\text { Goodness of Fit Index } \\
\text { (GFI) }\end{array}$ & 0.99 & $\begin{array}{c}\geq \\
0.90\end{array}$ & $\begin{array}{c}\text { Good } \\
\text { Fit }\end{array}$ \\
\hline \multicolumn{4}{|l|}{$\begin{array}{l}\text { Incremental Fit } \\
\text { Model }\end{array}$} \\
\hline $\begin{array}{l}\text { Comparative Fit } \\
\text { Index (CFI) }\end{array}$ & 0.99 & $\begin{array}{c}\geq \\
0.90\end{array}$ & $\begin{array}{l}\text { Good } \\
\text { Fit }\end{array}$ \\
\hline $\begin{array}{l}\text { Normed Fit Index } \\
\text { (NFI) }\end{array}$ & 0.96 & $\begin{array}{c}\geq \\
0.90\end{array}$ & $\begin{array}{l}\text { Good } \\
\text { Fit }\end{array}$ \\
\hline $\begin{array}{l}\text { Non-Normed Fit } \\
\text { Index (NNFI) }\end{array}$ & 0.99 & $\begin{array}{l}\geq \\
0.90\end{array}$ & $\begin{array}{l}\text { Good } \\
\text { Fit }\end{array}$ \\
\hline $\begin{array}{l}\text { Incremental Fit Index } \\
\text { (IFI) }\end{array}$ & 0.99 & $\begin{array}{c}\geq \\
0.90\end{array}$ & $\begin{array}{c}\text { Good } \\
\text { Fit }\end{array}$ \\
\hline $\begin{array}{l}\text { Relative Fit Index } \\
\text { (RFI) }\end{array}$ & 0.95 & $\begin{array}{c}\geq \\
0.90\end{array}$ & $\begin{array}{c}\text { Good } \\
\text { Fit }\end{array}$ \\
\hline \multicolumn{4}{|l|}{$\begin{array}{l}\text { Parsimonious Fit } \\
\text { Model }\end{array}$} \\
\hline $\begin{array}{l}\text { Adjusted Goodness of } \\
\text { Fit Index (AGFI) }\end{array}$ & 0.96 & $\begin{array}{c}\geq \\
0.90\end{array}$ & $\begin{array}{c}\text { Good } \\
\text { Fit }\end{array}$ \\
\hline
\end{tabular}

\begin{tabular}{lccc}
\hline Ukuran Kecocokan & $\begin{array}{c}\text { Hasil } \\
\text { Per- } \\
\text { Keseluruhan Model }\end{array}$ & $\begin{array}{c}\text { Syar } \\
\text { hitunga } \\
\text { n }\end{array}$ & $\begin{array}{c}\text { Ketera } \\
\text { ngan }\end{array}$ \\
\hline $\begin{array}{l}\text { Parsimony Goodness } \\
\text { of Fit Index (PGFI) }\end{array}$ & 0.70 & $\begin{array}{c}\geq \\
0.50\end{array}$ & $\begin{array}{c}\text { Good } \\
\text { Fit }\end{array}$ \\
\hline Source: LISREL 8.7 & & & \\
\hline
\end{tabular}

Setelah diperoleh keseluruhan model fit yang baik, dilanjutkan dengan uji hipotesis untuk menjawab rumusan masalah pada penelitian ini. Hasil uji hipotesis terdapat pada Tabel 3, menunjukkan koefisien jalur dan t-hitung menjelaskan hubungan dan pengaruh antara perilaku penggunaan dan kecocokan teknologi. Dari hasil pengujian hipotesis dapat dijelaskan bahwa semua hipotesis dibangun berdasarkan fakta yang didapat, adalah positif (koefisen jalur $=0,75 ; 0,59$; $0,62 ; 0,49 ; 0,42 ; 0,16 ; 0,17 ; 0,13)$ dengan nilai t-hitung $(16.08,15.03,10.35,11.34$, $9.08,7.81,6.56$, dan 6.78). Temuan ini menunjukkan bahwa NTF berpengaruh positif dan signifikan terhadap use intensity dan use variety, semakin meningkat kecocokan teknologi untuk memenuhi kebutuhan pengguna, maka akan semakin meningkat pula intensitas dan variasi penggunaan layanan seluler.

Tabel 3. Hasil Uji Hipotesis

\begin{tabular}{llcc}
\hline & Hipothesis & $\begin{array}{c}\text { Koefisien } \\
\text { Standardize }\end{array}$ & t-hitung \\
\hline H1 & $\begin{array}{l}\text { needs technologi } \\
\text { fit } \rightarrow \text { use intensity }\end{array}$ & 0.76 & $16.08^{* *}$ \\
H2 & $\begin{array}{l}\text { needs } \\
\text { technology } \\
\text { fit } \rightarrow \text { use variety }\end{array}$ & 0.59 & $15.03^{* *}$ \\
& &
\end{tabular}




\begin{tabular}{|c|c|c|c|}
\hline & Hipothesis & $\begin{array}{c}\text { Koefisien } \\
\text { Standardize }\end{array}$ & t-hitung \\
\hline \multirow[t]{2}{*}{ H3 } & technology & & \\
\hline & $\begin{array}{l}\text { functionality } \\
\text { fit } \rightarrow \text { use intensity }\end{array}$ & 0.62 & $10.35^{* *}$ \\
\hline \multirow[t]{2}{*}{$\mathrm{H} 4$} & technology & & \\
\hline & $\begin{array}{l}\text { functionality } \\
\text { fit } \rightarrow \text { use variety }\end{array}$ & 0.49 & $11.34 * *$ \\
\hline H5 & $\begin{array}{l}\text { use intensity } \rightarrow \\
\text { needs technology } \\
\text { fit }\end{array}$ & 0.42 & $9.08 * *$ \\
\hline H6 & $\begin{array}{l}\text { use variety } \rightarrow \\
\text { needs } \\
\text { technology fit }\end{array}$ & 0.16 & $7.81 * *$ \\
\hline H7 & $\begin{array}{l}\text { use intensity } \rightarrow \\
\text { technology } \\
\text { functionality fit }\end{array}$ & 0.17 & $6.56^{* *}$ \\
\hline H8 & $\begin{array}{l}\text { use variety } \rightarrow \\
\text { technology } \\
\text { functionality fit }\end{array}$ & 0.13 & $6.78 * *$ \\
\hline
\end{tabular}

Selain itu, TFF juga berpengaruh signifikan dan nyata terhadap use intensity dan use variety, dimana semakin meningkat kecocokan interoperabilitas teknologi dengan berbagai fungsi dan fitur gawai, maka akan semakin meningkat pula intensitas dan variasi penggunaan layanan seluler. Sebaliknya, hasil uji juga menunjukkan bahwa use intensity berpengaruh secara positif dan nyata terhadap NTF dan TFF demikian pula hanya dengan use variety. Artinya semakin tinggi intensitas penggunaan dan semakin luas variasi penggunaan layanan seluler meningkatkan pula kecocokan teknologi dan kebutuhan pengguna melalui aksesibitas yang fleksibel melalui beragam gawai.

Hasil penelitian ini menemukan pengaruh kecocokan teknologi dengan kebutuhan (NTF) dan kecocokan teknologi dengan fungsionalitas gawai (TFF) terhadap dua faktor penentu perilaku penggunaan, yaitu use intesity dan use variety yang mengindikasikan penggunaan berulang untuk tetap menggunakan layanan seluler yang telah dipilih pengguna tersebut. Hal ini diperkuat dengan kenyataan bahwa teknologi seluler yang berkembang terus secara cepat dan dinamis diringi dengan pesatnya pertumbuhan gawai seluler yang menawarkan beragam fitur terbaru yang dapat memenuhi keinginan dan kebutuhan pengguna. Hasil ini konsisten dengan penelitian Lin (2016) bahwa faktor-faktor yang dapat memenuhi kesesuaian teknologi akan memperngaruhi perilaku penggunaan dan penggunaan berulang. Fleksibilitas teknologi seluler membuat pengguna dapat mempersonalisasikan fungsi gawai berdasarkan kebutuhan. Persepsi teknologi pada individu dapat membatasi sekaligus meemnuhi kebutuhan untuk mencapai tujuan (Negahban 2012). Pengalaman pengguna merasakan kapabilitas dan fungsionalitas teknologi seluler dan gawai dalam memenuhi kebutuhannya, maka selanjutnya perilaku penggunaan teknologi seluler menjadi sebuah rutinitas (Leonardi 2011).

Selain itu, temuan menarik adalah perilaku penggunaan use intensity dan use variety berpengaruh terhadap NTF dan TFF, hal ini mengandung arti adanya hubungan saling mempengaruhi diantara ke-empat fator 
tersebut. Hal ini sejalan dengan perilaku penggunan berbasis model use diffusion. Use intensity dan use variety mengukur rentang waktu dan penggunaan teknologi; frekuensi pengguna mengakses jaringan seluler, apakah pengguna memanfaatkan sebagian besar fitur ponsel untuk mengakses layanan seluler, atau hanya dua atau tiga jenis layanan dan jumlah layanan yang digunakan bersamaan. Pengguna dengan penggunaan intensif lebih puas dengan teknologi daripada penggunaan terbatas (Hau, Kim, and Kim 2012). (Gerpott 2010) menyatakan bahwa intensitas penggunaan layanan broadband tidak terbentuk dari kepercayaan subyektif, tetapi lebih pada kondisi penggunaan faktual seperti tarif, kualitas jaringan dan gawai seluler. Ditambahkan oleh (Olson et al. 2011), ragam penggunaan fitur dan aktivitas penggunaan layanan merupakan indikasi pengetahuan seseorang tentang teknologi tersebut. Perbedaan intensitas dan ragam penggunaan mencerminkan kepercayaan yang tumbuh dengan teknologi sehingga dapat memprediksi teknologi baru yang akan diadopsi. Selain itu perilaku penggunaan menyiratkan layanan seluler dari operator dapat memenuhi kebutuhan yang diperoleh dari layanan yang disediakan operator yang telah dipilihnya. Perlu diperhatikan pula, penelitian klasik selanjutnya dari (Bolton dan Lemon 1999) mempertimbangkan bahwa perilaku penggunaan secara individual terjadi setelah memiliki hubungan formal dengan MNO yang memberikan beragam layanan seluler secara terus menerus. Temuan ini menunjukkan bahwa pengguna akan terus menggunakan layanan seluler meskipun teknologi seluler berubah terus menerus secara cepat.

\section{SIMPULAN DAN SARAN}

Hasil penelitian menunjukkan bahwa secara umum pengguna mengutamakan kecocokan teknologi untuk memenuhi kebutuhan utilitas maupun kesenangan yang diperoleh dari layanan broadband. Kecocokan teknologi seluler dengan kebutuhan pengguna mobile services memiliki nilai kontribusi tertinggi dalam mempengaruhi intensitas penggunaan. Teknologi seluler yang memenuhi kebutuhan pengguna akan dikonsumsi terus menerus dengan intensitas yang tinggi. Seiring dengan hal tersebut, intensitas penggunaan juga berpengaruh cukup tinggi terhadap kecocokan teknologi dengan kebutuhan. Hal ini menunjukkan bahwa perkembangan teknologi yang dinamis dapat meningkatkan penggunaan melalui layanan inovatif layanan broadband.

Selain itu, kecocokan fungsionalitas teknologi gawai juga memberikan kontribusi yang tinggi pada intensitas penggunaan. Kemajuan teknologi gawai dan teknologi seluler menawarkan ragam layanan 
broadband yang dapat diakses, sehingga pengguna akan mengkonsumsi variasi layanan secara bersamaan yang akan berujung pada penggunaan berkelanjutan dengan intensitas tinggi.

Bagi para praktisi di industri telekomunikasi, hasil penelitian ini dapat memberikan beberapa implikasi bagi operator seluler (MNO). Untuk meningkatkan ARPU, dapat dilakukan dengan cara mendapatkan pelangan baru dan mempertahankan yang sudah ada dengan menawarkan layanan broadband yang inovatif benilai tambah bagi penggunanya. Dengan variasi penggunaan layanan yang luas seperti berkomunikasi, mengakses search engine, maps, aplikasi over the top, vídeo, mobile money, games, GPS tracking, LTE home, VoLTE (voice over LTE) dan lainnya. Perilaku penggunaan menjadi kunci keberhasilan dalam meningkatkan pendapatan. Semakin tinggi konektivitas seluler dan semakin besar volume penggunaan jaringan seluler akan menambah pendapatan MNO yang terindikasi dari minutes of usage dan payload layanan broadband.

Teknologi seluler menjadi basis dalam memberikan layanan digital yang dapat digunakan kapanpun dan dimanapun. Temuan penelitian ini menunjukkan bahwa perilaku penggunaan dipengaruhi oleh teknologi yang dapat memenuhi kebutuhan konsumen. Oleh sebab itu seiring dengan perubahan teknologi, MNO mutlak harus pemutakhiran jaringan dengan kualitas yang handal guna menyediakan layanan prima. Di samping itu, pemeliharaan dan optimalisasi jaringan, peningkatan kapasitas dan kapabilitas jaringan seluler merupakan suatu keniscayaan. Di sisi lain, perkembangan gawai seluler yang semakin canggih juga memberikan peluang bagi MNO untuk menyediakan layanan teknologi seluler yang sesuai dengan fitur gawai yang terbaru. Dari sisi pemasaran, MNO dapat bekerjasama dengan pabrikan gawai untuk menawarkan program bundling ekslusif dengan harga yang atraktif untuk dapat memenuhi kebutuhan pengguna yang bersifat khusus, seperti bersosialisasi, hiburan, dan aplikasiaplikasi lain yang diperlukan dan diinginkan konsumen di era digital lifestyle ini.

Pola perilaku penggunaan menyiratkan penggunaan berulang, mengingat kesesuaian layanan seluler dengan kebutuhan pengguna dan fungsionalitas gawai untuk konektivitas jaringan seluler. Dengan demikian, operator seluler dapat lebih agresif menjawab tantangan pasar telekomunikasi melalui berkolaborasi dengan produsen gawai dan penyedia layanan aplikasi dan konten, seperti layanan over the top, berupa product bundling dan aplikasi atau konten bundling dengan penawaran yang atraktif. 
Penelitian ini memiliki beberapa keterbatasan. Pertama, penelitian ini spesifik hanya dilakukan di satu wilayah, sehingga tidak dapat digenelalisir untuk daerah-daerah yang sosio demografisnya berbeda. Kedua, pelaku industri telekomunikasi bukan saja MNO dan konsumen, namun terdapat beberapa pihak di dalam mobile ecosystem, oleh sebab itu perlu dilakukan penelitian lebih jauh lagi pada pengembang aplikasi dan konten, produsen gawai, penyedia layanan broadband lainnya seperti internet provider, Mobile Virtual Network Operator (MVNO) dan lainnya. Ketiga, berdasarkan temuan (Dabholkar dan Bagozzi 2002), menunjukkan bahwa self technology mampu mempengaruhi kecepatan layanan (akses jaringan seluler) dan juga akan mempengaruhi sikap konsumen terhadap teknologi. Oleh sebab itu, disarankan untuk melakukan penelitian lebih lanjut dengan menambahla variabel lainnya seperti karakteristik teknologi seluler serta perilaku pengguna untuk mendapatkan kesesuaian teknologi seluler dengan kebutuhan gaya hidup digital.

\section{DAFTAR PUSTAKA}

APJII, and MASTEL. (2018). "Penetrasi \& Perilaku Pengguna Internet Indonesia."

Annual Report. (2018). Laporan Keuangan Operator Seluler Telkomsel, IndosatOoredo, XL-Axiata. Investor Relation.

Bolton, Ruth N, and Katherine N Lemon.
(1999). “A Dynamic Model of Customers ' Usage of Services : Usage as an Antecedent and Consequence of Satisfaction." Journal of Marketing Research XXXVI (May),171-86.

Dabholkar, Pratibha A, and Richard P Bagozzi. (2002). “An Attitudinal Model of Technology-Based Self-Service : Moderating Effects Of ...” 30 (3), 184201.

Hootsuit We're Social. (2020). Digital Indonesia 2020. January 2020.

Dishaw, Mark $\mathrm{T}$, and Diane $\mathrm{M}$ Strong. (1998). "TTF and TAM Models" 36, 921.

http://citeseerx.ist.psu.edu/viewdoc/do wnload?

Fernández, Zulima, and Belén Usero. (2009). "Competitive Behavior in the European Mobile Telecommunications Industry: Pioneers vs. Followers." Telecommunications Policy 33 (7), 339-47.

Flew, T. (2005). New Media and Introduction. $2^{\text {nd }}$ Edition. United Kingdom: Oxford University Press.

Gardial, Sarah F, D Scott Clemons, Robert B Woodruff, David W Schumann, and Mary Jane Burns. (2004). "Comparing Consumers ' Recall of Prepurchase and Postpurchase Product Evaluation Experiences." Journal of Consumer Research 20 (March 1994), 548-60.

Gazis, Vangelis, Nikos Houssos, Nancy Alonistioti, and Lazaros Merakos. (2003). "On the Complexity of " Always Best Connected ' in 4G Mobile Networks." Vehicular International Conference IEEE 38th. 4 (4), 2312-16. http://citeseerx.ist.psu.edu/viewdoc/su mmary?

Gebauer, Judith, Michael J Shaw, Michele L Gribbins, Judith Gebauer, Michael J 
Shaw, and Michele L Gribbins. (2005). "Towards a Specific Theory of Task Technology Fit for Mobile Information Systems." Journal of Strategic Information System, 1-52.

Gerpott, Torsten J. (2010). “Communication Behaviors and Perceptions of Mobile Internet Adopters." Info. Emerald Publishing 12 (4), 54-73.

Ghezzi, Antonio, Marcelo Nogueira Cortimiglia, and Alejandro Germán Frank. (2015). "Strategy and Business Model Design in Dynamic Telecommunications Industries: A Study on Italian Mobile Network Operators." Technological Forecasting and Social Change 90 (PA),346-54.

Goodhue, Dale L, and Ronald L Thompson. (1995). "Task-Technology Fit and Individual Performance." MIS Quarterly: Management Information Systems 10 (3): 278-88.

Hamblin, Robert L, Jerry L L Miller, and D. Eugene Saxton. (1979). "Modeling Use Diffusion *." Social Forces 53 (3), 799811.

Hair, J.F., Anderson, R.F., Black, W.C. (2007). Multivariate Data Analysis: A Global Perspective. Seventh Edition, Prentice Hall. New Jersey, USA.

Hau, Young Sauk, Geonha Kim, and Byoungsoo Kim. (2012). "Antecedents of User Satisfaction in the Context of Mobile Data Services: The Moderating Role of Variety and Rate of Usage Yong Sauk Hau Geonha Kim." International Journal Mobile Communication, 10 (6), 617-36.

Ju, Su Yi. 2011. "Telecom Upgraded Services Adoption Model Using the Use - Diffusion Theory: The Study of China'S Telecommunications Market." International Journal of Organizational Innovation, 4 (2),77-122.
Kim, Hee-woong, Hock Chuan Chan, and Sumeet Gupta. (2007). "Value-Based Adoption of Mobile Internet: An Empirical Investigation." Decision Support Systems 43,111-26.

Klopping, Inge $\mathrm{M}$, and Earl Mckinney. (2004). "Extending the Technology Acceptance Model and the TaskTechnology Fit Model to Consumer eConsumer." Information Technology, Learning, and Performance Journal 22 (1),35-48.

Kotler, P., Armstrong, G. (2011). Principles of Marketing. 14 ${ }^{\text {th }}$ Edition. Pearson Education, Inc. Prentice Hall. New Jersey. NJ.

Kwai Fun IP, Rachael, and Christian Wagner. (2008). "Weblogging: A Study of Social Computing and Its Impact on Organizations." Decision Support Systems 45 (2), 242-50.

Leonardi, Paul M. (2011). "When Flexible Routines Meet Flexible Technologies: Affordance, Constraint, and the Imbrication of Human and Material Agencies." MIS Quarterly: Management Information Systems 35 (1): 147-67.

Lin, Kuan Yu. (2016). "User Communication Behavior in Mobile Communication Software." Online Information Review,40 (7): 1071-89.

Lin, Wen-shan. (2012). "Perceived Fit and Satisfaction on Web Learning Performance: IS Continuance Intention and Task-Technology Fit Perspectives." Journal of Human Computer Studies 70 (7), 498-507.

Liu, Chung Tzer, Yi Maggie Guo, and Chia Hui Lee. (2011). "The Effects of Relationship Quality and Switching Barriers on Customer Loyalty." International Journal of Information Management 31 (1), 71-79. 
Lu, Hsi Peng, and Yi Wen Yang. (2014). "Toward an Understanding of the Behavioral Intention to Use a Social Networking Site: An Extension of TaskTechnology Fit to Social-Technology Fit." Computers in Human Behavior 34,323-32.

Ministry of Communication and Informatics. (2018). "Survey Penggunaan Teknologi Informasi Dan Komunikasi."

Motohashi, Kazuyuki, Deog-ro Lee, Yeongwha Sawng, and Seung-ho Kim. (2012). "Innovative Converged Service and Its Adoption, Use and Diffusion: A Holistic Approach to Diffusion of Innovations , Combining AdoptionDiffusion and Use-Diffusion Paradigms." Journal of Business Economics and Management, no. October 2014,37-41.

Negahban, Arash. (2012). "Factors Affecting Individual's Intention to Purchase Smartphones from Technology Adoption and Technology Dependence Perspectives." 18th Americas Conference on Information Systems 2012, AMCIS 2012 (5),3679-3689.

Negahban, Arash, and Chih-hung Chung. (2014). "Computers in Human Behavior Discovering Determinants of Users Perception of Mobile Device Functionality Fit." Computers in Human Behavior, 35, 75-84.

Olson, Katherine E, Marita A O Brien, Wendy A Rogers, and Neil Charness. (2011). "Diffusion of Technology: Frequency of Use for Younger and Older Adults." Ageing International, 36,123-45.

Preez, Gert T. Du, and Carl W.I. Pistorius. (2003). "Analyzing Technological Threats and Opportunities in Wireless Data Services." Technological Forecasting and Social Change 70 (1): $1-20$.
Ram, S, and Hyung-Shik Jung. (1990). "The Conceptualization and Measurement of Need." Journal of the Academy of Marketing Science, 18 (1): 67-76. http://books.google.com/books?hl=en\& $\mathrm{lr}=\& \mathrm{id}=\mathrm{hRuIAgAAQBAJ} \&$ pgis=1 .

Ramirez-Correa, Patricio E., F. Javier Rondan-Cataluña, and Jorge ArenasGaitán. (2015). "Predicting Behavioral Intention of Mobile Internet Usage." Telematics and Informatics 32 (4): 834 41.

https://doi.org/10.1016/j.tele.2015.04.0 06.

Reuver, Mark De, Guido Ongena, and Harry Bouwman. (2013). "Should Mobile Internet $\mathrm{Be}$ an Extension to the Fixed Web? Fixed-Mobile Reinforcement as Mediator between Context of Use and Future Use." Telematics and Informatics, 30 (2),111-20.

Ridgeway, Nancy M, and Linda L Price. (1994). "Exploration in Product Usage : A Model of Use Innovativeness : ABSTRACT." Psychology \& Marketing,11 (1),69-85.

Sarker, Supratek, and John D. Wells. (2003). "Understanding Mobile Handheld Device Use and Adoption." COMMUNICATIONS OF THE ACM, 2003.

Sawng, Yeong-Wha, K Motohashi, and Gang-hoon Kim. (2013). "Comparative Analysis of Innovative Diffusion in the High-Tech Markets of Japan and South Korea: A Use - Diffusion Model Approach.” Service Business. Springer. 7: 143-66.

Shih, Chuan-fong, and Alladi Venkatesh. (2004). "Beyond Adoption: Development and Application of a UseDiffusion Model" 68 (January), 59-72.

Shin, Dong Hee, and Yong Jin Park. (2017). "Understanding the Internet of Things 
Ecosystem: Multi-Level Analysis of Users, Society, and Ecology." Digital Policy, Regulation and Governance, 19 (1), 77-100.

Shin, Jungwoo, Jae Young Choi, and Daeho Lee. (2016). "Model for Studying Commodity Bundling with a Focus on Consumer Preference: Evidence from the Korean Telecommunications Market." Simulation: Transactions of the Society for Modelling and Simulation International, 92 (4), 31121.

https://doi.org/10.1177/0037549716638 838.

Soegardo, Garuda. (2017). Garuda Soegardo Mobile, Telkomsel The First Era. Yrama Widya. Bandung.

Srinuan, Chalita, Pratompong Srinuan, and Erik Bohlin. (2013). "Telematics and Informatics An Analysis of Mobile Internet Access in Thailand: Implications for Bridging the Digital Divide." Telematics and Informatics, 29 (3),254-62.

Venkatesh, Alladi, Erik Kruse, and Eric Chuan-Fong Shih. (2003). "The Networked Home: An Analysis of Current Developments and Future Trends." Cognition, Technology \& Work, 5 (1), 23-32.

Yen, David C., Chin Shan Wu, Fei Fei Cheng, and Yu Wen Huang. (2010a). "Determinants of Users' Intention to Adopt Wireless Technology: An Empirical Study by Integrating TTF with TAM." Computers in Human Behavior,26 (5), 906-15.

Yen, David C, Chin-shan Wu, Fei-fei Cheng, and Yu-wen Huang. (2010b). "Computers in Human Behavior Determinants of Users ' Intention to Adopt Wireless Technology: An Empirical Study by Integrating TTF with TAM." Computers in Human
Behavior, 26 (5),906-15.

Zhang, Jing, and Xiong Jian Liang. (2011). "Business Ecosystem Strategies of Mobile Network Operators in the 3G Era: The Case of China Mobile." Telecommunications Policy, 35 (2),156-71.

Zhou, Tao, Yaobin Lu, and Bin Wang. (2010). "Computers in Human Behavior Integrating TTF and UTAUT to Explain Mobile Banking User Adoption." Computers in Human Behavior, 26 (4),760-67. 